\title{
Sistem Pengambilan Keputusan Mengunakan Metode Ahp Untuk Menentukan Siswa Yang Berperilaku Menyimpang Dari Pengaruh Internet (Studi Kasus Smp Negeri 17 Padang)
}

\author{
Yanti Yusman \\ Dosen Unidha Padang \\ yantiyusman@yahoo.co.id
}

\begin{abstract}
ABSTRAK
The role of Internet technology rapidly advancing education among a lot of the gains due to the presence of the Internet makes it easy to search the subject matter, but there are also some boys and girls who misuse the internet therefore the authors are interested in completing these cases the extent of the role the Internet for students and girls in school after field research there are several answers of boys and girls in schools used the Internet to answer Nonto vidio porn , pornography stored and mature discussion so to answer this writer is interested to know the deviant behavior among male and female students of the school.
\end{abstract}

Kata Kunci: Sistem, keputusan, AHP, internet

\section{PENDAHULUAN}

Informatika sudah menjadi pilihan utama dalam menciptakan sistem informasi yang tangguh. Perkembangan zaman saat ini diwarnai dengan kemajuan teknologi yang luas, salah satunya adalah teknologi internet, selain dampak negatif, internet juga banyak member dampak positif pada Siswa-Siswi Sekolah. Saat ini banyak siswa berperilaku menyimpang khususnya pada prilaku sex dunia internet yang masuk kedalam dunia pendidikan diantaranya dengan internet mempermudah mencari data dalam satu materi, dan dengan mudah mendapatkan informasi yang sesuai dengan apa yang kita inginkan. Banyak informasi yang kita dapatkan secara cuma-cuma melalui internet Peranan perilaku menyimpang saat ini banyak siswa berperilaku sex di usia dini karena internet merupakan media informasi yang bisa di update kapan saja sehinga Perkembangan teknologi informasi memungkinkan pengambilan keputusan dan informasi dapat dilakukan secara cepat sesuai dengan perkembangan penggunaankomputer. penyajian data dan informasi sangat tergantung pada perangkat lunak (software) yang digunakan. Di SMP NEGERI 17 PADANG ada beberapa siswa yang dicurigai karena menyalah gunakan teknologi informasi untuk mengakses hal-hal yang berbau menyimpang sehingga siswa tersebut dicurigai berperilaku menyimpang.

\section{METODE PENELITIAN}

Metode penelitian adalah gambaran langkah-langkah yang akan dilakukan dalam penelitian. Hal ini perlu ditetapkan agar penelitian dapat dilakukan dengan terstruktur. Maka disini ditetapkan beberapa tahapan yang akan dilakukan pembahasan masingmasing kegiatan sebagai berikut :

a. Mendefinisikan Masalah

Pada tahap ini dilakukan peninjauan kesistem yang akan diteliti untuk mengamati serta melakukan eksplorasi lebih dalam dan menggali permasalahan yang ada. 


\section{Jurnal Edik Informatika}

ISSN : 2407-0491

E-ISSN : 2541-3716

Penelitian Bidang Komputer Sains dan Pendidikan Informatika

V3.i1(1-7)

b. Menganalisa Masalah

Langkah ini merupakan langkah untuk memahami masalah yang telah ditentukan dalam ruang lingkup atau batasannya. Dengan menganalisa masalah yang ditentukan tersebut, maka masalah dapat dipahami dengan baik.

c. MenentukanTujuan

Berdasarkan rumusan masalah yang telah dibuat pada tahap sebelumnya, maka tahap penentuan tujuan berguna untuk memperjelas kerangka tentang apa saja yang menjadi sasaran dari penelitian ini. Pada tahap ini ditentukan tujuan dari penelitian adalah bagaimana merancang dan mengimplementasikan suatu sistem dengan metode Analytical Hierarchy Process yang akandigunakandalam Proses Pengambilan keputusan.

d. Mempelajari Literatur

Untuk mencapai tujuan yang telah ditentukan, maka perlu dipelajari beberapa literatur-literatur yang digunakan. Literatur-literatur yang dipelajari tersebut diseleksi untuk dapat ditentukan literature mana yang akan digunakan dalam penelitian. Studi pustaka dilakukan dengan tujuan untuk mengetahui metode apa yang akan digunakan untuk menyelesaikan permasalahan yang akan diteliti, serta mendapatkan dasar-dasar referensi yang kuat bagi peneliti dalam menerapkan suatu metode yang digunakan.

e. Mengumpulkan Data

Pada tahap ini dilakukan pengumpulan data untuk lebih mengetahui sistem yang diteliti. Dari data dan informasi yang dikumpulkan akan dapat diketahui mengenai sistem saat ini.

\section{HASIL DAN PEMBAHASAN}

Dalam pengolahan data ini ada beberapa kriteria dan alternatif yang digunakan untuk menentukan siswa yang berperilaku menyimpang dari pengaruh internet, diantaranya adalah untuk criteria akses youtube, diskusi dewasa, akses web porno, menyimpan gambar porno, dan mempuyai BlackBerry, alternatifnya adalah siswa.

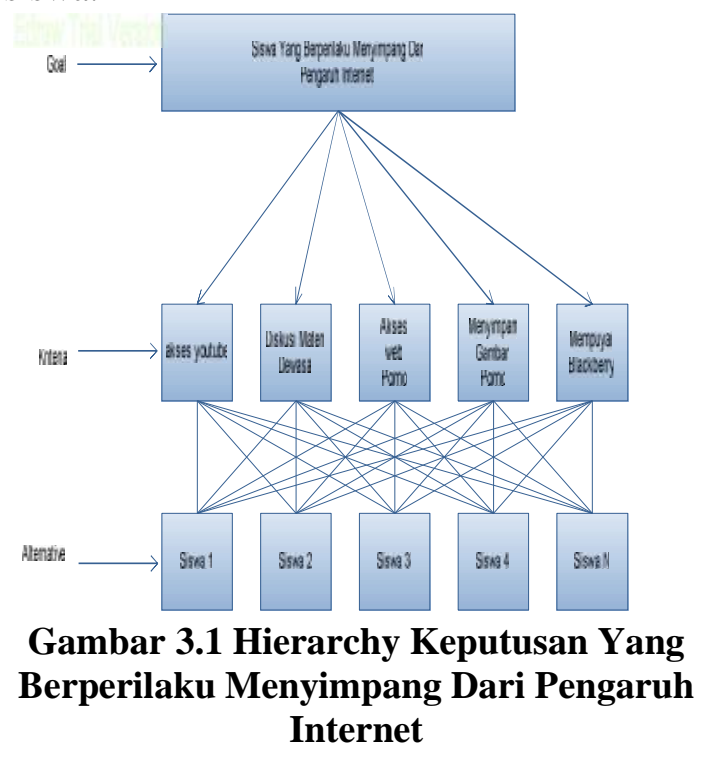

\subsection{Implementasi}

Langkah -langkah pengolahan data dilakukan dengan cara sebagai berikut:

1. Mengaktifkan perangkat lunak super decision yang sudah di install pada computer dengan tampilan awal sebagai berikut : 


\section{Jurnal Edik Informatika}

ISSN : 2407-0491

E-ISSN : 2541-3716

Penelitian Bidang Komputer Sains dan Pendidikan Informatika

V3.i1(1-7)

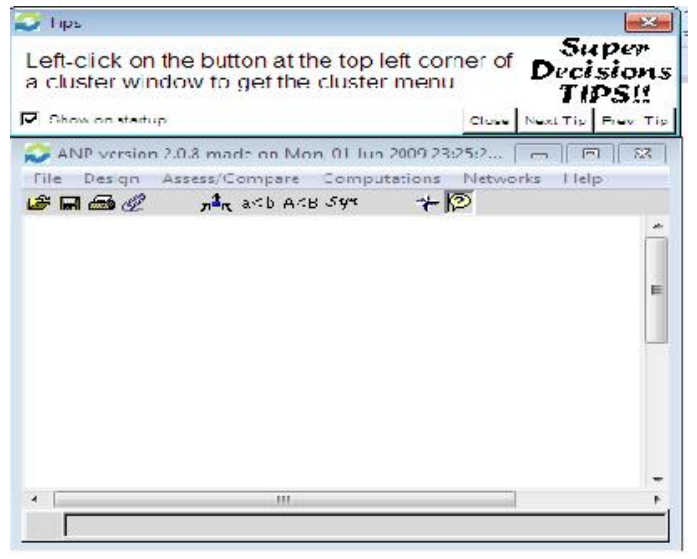

\section{Gambar 3.2Tampilan Awal Super} Desicions

2. Dari menu window utama, pilih Disign, Cluster, New untuk menciptaan Cluster pertama. Cluster yang baru akan muncul kotak dialog seperti pada gambar 3.2atau cara lain dengan menekan $\langle$ shift $\rangle$ dan $\langle\mathrm{n}\rangle$ secara bersamaan dan menginputkan nama kedalam cluster

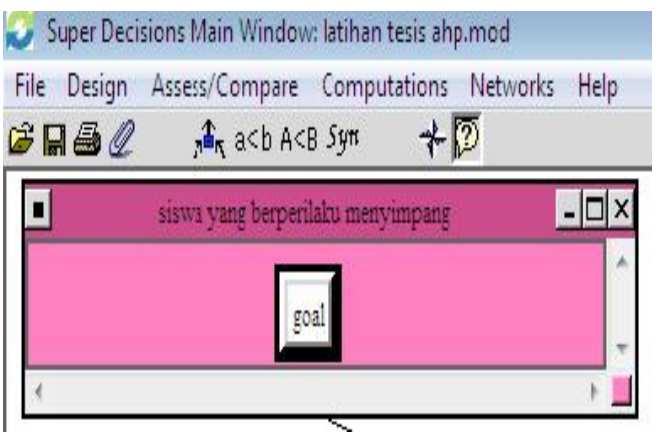

\section{Gambar 3.2 Kotak Dialog Cluster Goal}

3. Dalam pembuatan nama-nama cluster dimulai dengan angka-angka untuk mengatur urutan, karena semua akan ditampilkan dalam abjad di supermatriks.

4. Ketik 1Goal pada name dan "Sistem Penunjang Keputusan Mengunakan Metode AHP Untuk Menentukan Siswa Yang Berperilaku Menyimpang Dari Pengaruh Internet.
5. Pada New Cluster Dialog berikutnya Ketik 2 Kriteria pada name dan Ketik Kriteria Penelitian pada Description, seperti gambar berikut :

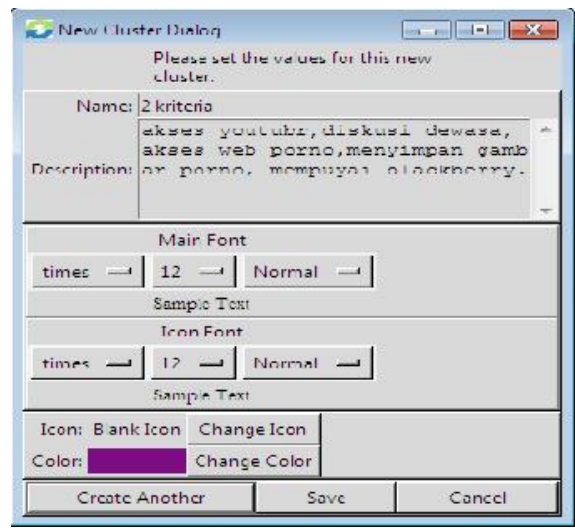

\section{Gambar 3.3 Cluster Kriteria}

Pada New Cluster Dialog Ketik 3 Alternatif pada name dan Ketik Hasil Penilaian pada Description, seperti gambar berikut :
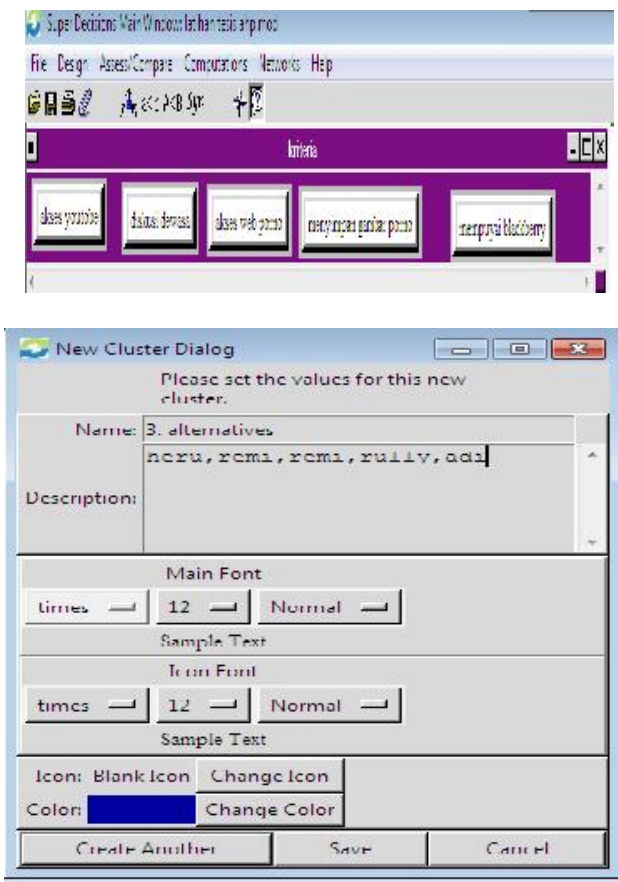


\section{Jurnal Edik Informatika}

ISSN : 2407-0491

Penelitian Bidang Komputer Sains dan Pendidikan Informatika

V3.i1(1-7)

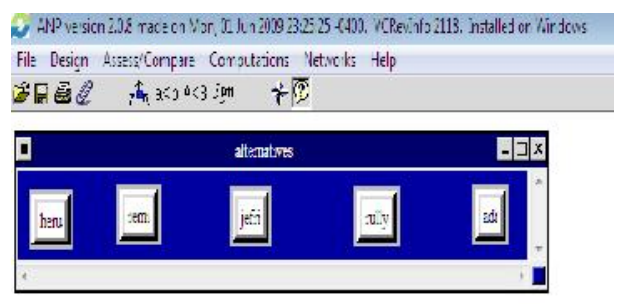

\section{Gambar 3.4 Cluster Alternatif}

6. Untuk mengakhiri pembuatan cluster pilih save untuk menyimpan dan mengakhiri proses panambahan cluster.

7. Mengatur cluster seperti yang di tujukan dibawah ini dengan mengklik pada judul baru dengan menyeret sesuai dengan keinginan kita. Untuk menghubungkan setiap elemen antara goal dengan criteria adalah dengan cara node bernama Tujuan yang menjadi parent atau sumber node. Dalam daftar yang sekarang muncul, klik kiri pada node criteria untuk memilih koneksi ada 2 cara menjalankanya :

a. Untuk menyambungkan dengan mengunakan "Make Connection"

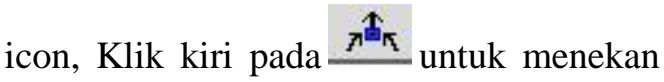
menampilkan modus koneksi, kemudian Klik kiri pada node sumber dan Klik kanan Pada Masing-masing node yang terhubung. Untuk menonaktifkan modus koneksi, klik kanan icon ulangi lagi untuk menekan hal itu

b. Untuk Memutuskan sambungan, Klik kiri Pada node dan Klik kanan pada salah satu dari node yang di uraikan dalam warna merah (yang sebelumnya sehubungan dengan itu ) untuk memutuskan sambungan.

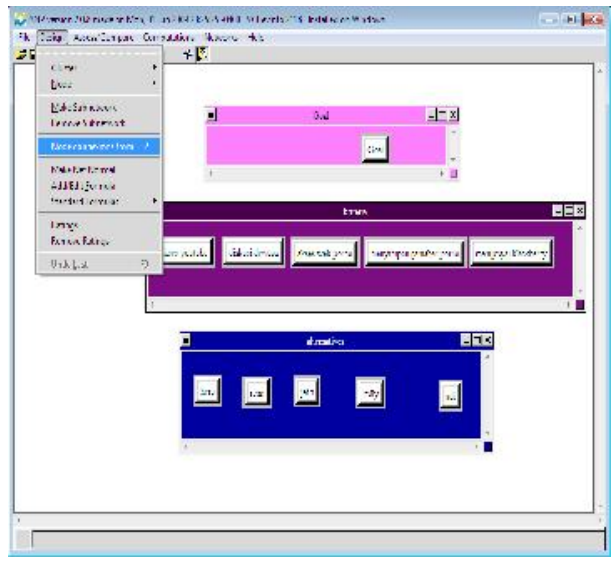

\section{Gambar 3.5 Menghubungkan masing- masing cluster}

8. Membuat cluster yang dikoneksikan Pilih design, node, New kemudian pilih 1 Goal dari daftar kelompok yang muncul untuk memasukan unsur dalam cluster. Masukan tujuan node dalam field nama dan deskripsi di kolom Description. Untuk memilih warna latar belakang Klik "change color" pada tombol dan pilih color. Pilih Font yang di inginkan. Tekan save untuk mengakhiri proses dalam memasukan node di cluster ini. Setelah semua cluster dan node terbentuk, selanjutnya menghubungkan node-node yang ada dalam cluster criteria dengan node-node yang ada dalam cluster akses youtube, diskusi dewasa, menyimpan gambar porno, akses web porno, dan mempuyai blackberry. Dengan node-node yang ada dalam cluster Alternative. 


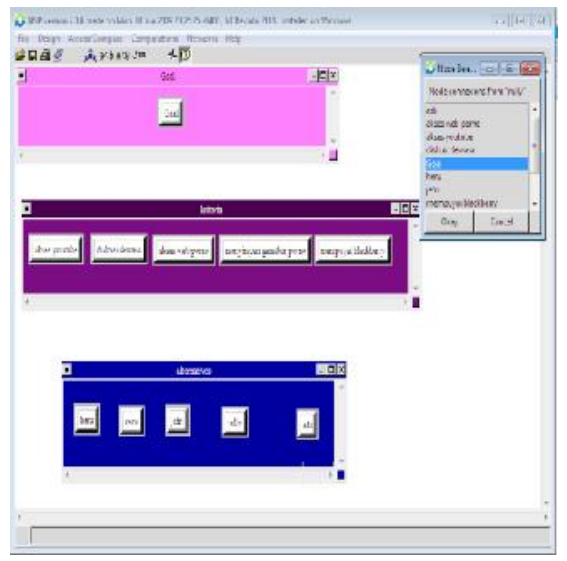

\section{Gambar 3.6 Cluster Yang dikoneksikan}

9. Shortcut untuk membuat node baru: Cari kursor Anda Pada latar belakang cluster tujuan dan tekan $\langle\mathrm{n}\rangle$. Pintas lain untuk membuat simpul baru: Klik kanan pada latar belakang dari cluster untuk mendapatkan menu drop-down perintah dah pilih "menciptakan node dalam cluster"

\section{Criteria Cluster}

1. Akses Youtobe

2. Diskusi Materi Dewasa

3. Akses Web Porno

4. Menyimpan Gambar Porno

5. Mempuyai BlackBarry

\section{Alternatif Cluster}
a. Heru
b. Remi
c. Rully
d. Jefri
e. Adi

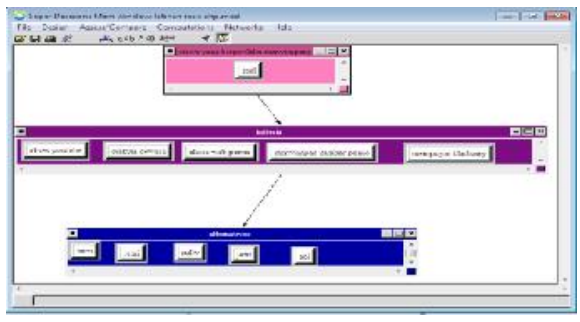

Gambar 3.7 koneksi semua Cluster
10.Pengujian perbandingan Matrik Berpasangan

Pilih Access / Compare, node comparations untuk memulai proses perbandingan. Jika node telah dipilih dengan mengkliknya

11.Klik pada tombol Do Comparison untuk memulai proses perbandingan. Proses perbandingan berpasangan dimulai dalam modus yang terakhir digunakan, atau dalam modus Questionnaire pertama kalinya. Ada empat mode penilaian perbandingan berpasangan. Untuk beralih dari satu mode ke mode yang lain Klik pada tab dibagian atas. Ketika sebuah penilaian dimasukan dalam satu modus yang tercatat dalam sebuah mode. Perhitungan didasarkan pada angka dalam modus, Matrik (dalam modus kuesioner selalu menunjukan bilangan bulat, tidak ada nomor yang ditampilkan dalam modus grafis dan Verbal )
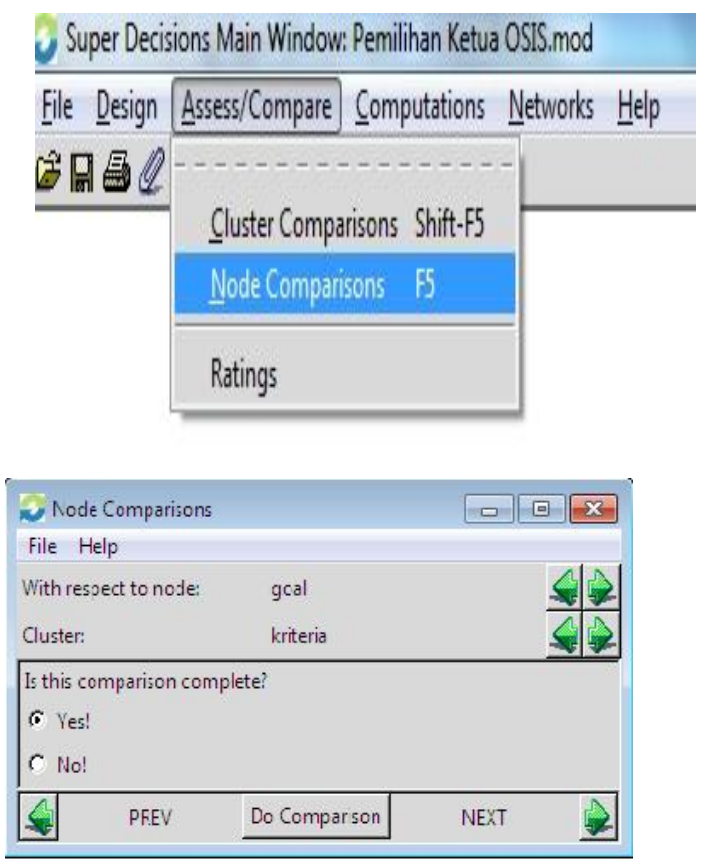

Gambar 3.8 Menu Perbandingan

5 Diterbitkan Oleh Program Studi Pendidikan Informatika STKIP PGRI Sumbar 


\subsection{Perhitungan Matrik Perbandingan Antar Kriteria}

Berdasarkan kriteria yang ditetapkan dapat diimplementasikan dalam perhitungan dengan mengunakan Software Desicions, perhitungan matrik tertinggi adalah diskusi dewasa yang dapat dilihat pada gambar dibawah ini :

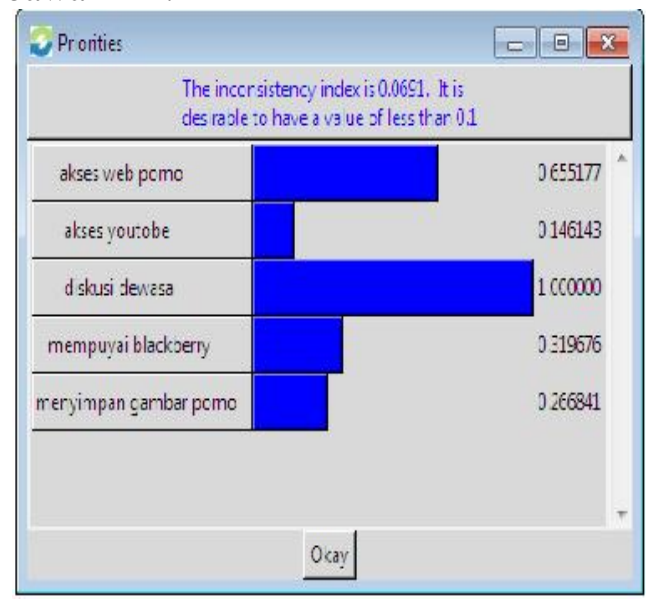

Gambar 3.9 Prioritas Kriteria

Untuk keluar dari modus perbandingan (comparison mode), Klik x di sudut kanan atas, pilih perintah Close File. Penilian numeric dibuat dalam matriks mengunakan skala Sembilan titik yang mewakili berapa kali satu unsur yang lebih penting dari pada yang lain. Panah di sebelah kiri entry point keunsur dominan. Untuk mengganti yang unsure dominan, kiri Menganalisa hasil komputasi AHP dengan menampilkan rasio konsistensi untuk perbandingan matriks setiap cluster. Klik ganda Pada panah.

Memasukkan nilai dari hasil kuisioner yang telah diisi oleh guru SMP cluster yang telah dikoneksikan pada tab menu matrix

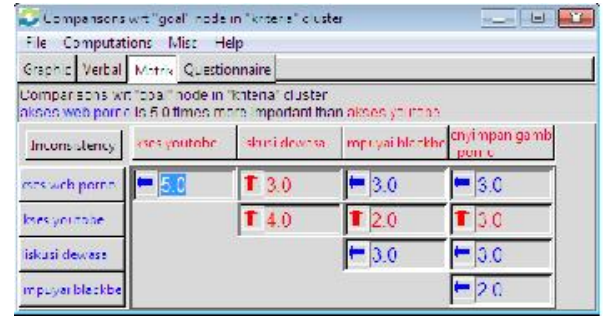

\section{Gambar 3.10. Nilai Dari Hasil Kuisioner}

Setelah semua nilai dari hasil kuisioner dimasukan, selanjutnya melakukan proses komputasi matriks. Klik menu computations, synthesize.
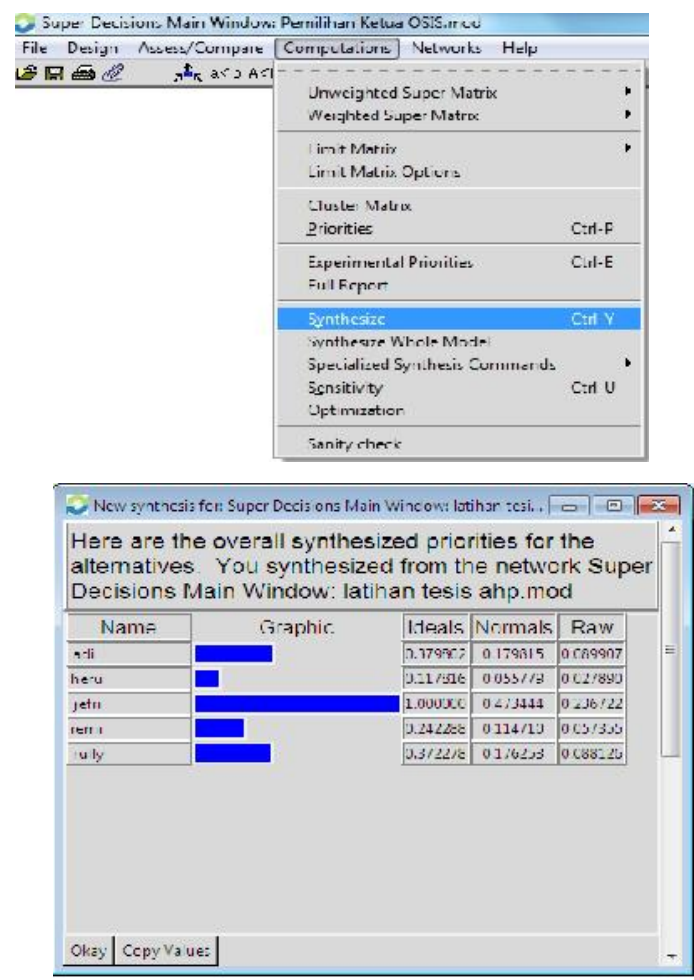

Gambar 3.11 Tabel Hasil Perhitungan Prioritas Menyeluruh

Menganalisa hasil komputasi AHP dengan menampilkan rasio konsistensi untuk perbandingan matriks setiap cluster.

Hasil ini menunjukan pada gambar 3.11 bahwa yang mempuyai prioritas menyeluruh terbesar ternyata siswa yang berperilaku menyimpang dari pengaruh 
internet terbesar adalah Jefri, kemudian berturut-turut diikuti oleh Adi, Rully, Heru, Remi.

\section{DAFTAR PUSTAKA}

Islam, Rafikul. Shuib. Employe Performasnce Evaluation By AHP : A Case Study. dlSAHP, Honolulu, Hawaii, 2005.

Jiaqin Yang, Ping Shi. Applying Analitic Hierarchy Process in Firm's Overall Performance Evaluation : A Case Study in China, international journal of business 7 (1), ISSN : 1083-4346, 2002.

Avangelos, Stuart. Using the Hierarchy Processfor Decision Makingin Enginering Applications:Some Challange.International Journal of Industrial Engineering, vol.2 No.1, pp. 35-44. 